\title{
The Urgency of Community Supervision of Local Government Administration
}

\author{
Anwar Sadat ${ }^{1}$, Muh. Askal Basir ${ }^{1}$, Nastia $^{1}$ \\ \{anwarsadat685@gmail.com\} \\ ${ }^{1}$ Universitas Muhammadiyah Buton
}

\begin{abstract}
The Optimization of local government performance can be measured through the high urgency of community supervision in its role as a controller of local government performance. Of course, community control is highly dependent on the management pattern applied by the local government, if the management pattern is applied closed management, the available public communication space is very minimal and tends to various distortions that lead to corruption, collusion and nepotism. Thus, transparency of local governments as a manifestation of the implementation of good governance must be encouraged through the form of management through publicity pledges to the public in laws to exercise social control, and inform various programs / activities, achievements, constraints, and the transparency agenda of local governments to public. On the other hand, the quality of people's preferences that provide input or control also needs to be known to one another in order to optimize government performance.
\end{abstract}

Keywords: Community Participation, Control, Performance of Government

\section{Introduction}

In every statutory regulation issued by the government, aspects of community participation or involvement must exist and become an integral part of all these regulations. The end of the New Order era towards a truly democratic era of the current Pancasila, this aspect of community involvement can be said to be very wide open. A government that implements closed management, state administration that is independent from social control and political control of the superstructure and political infrastructure, as well as an ideology of developmentism that is not based on a people's economy, has broad implications for the practices of corruption, collusion and nepotism $(\mathrm{KKN})$ in in government bodies. Therefore, the efforts to combat corruption, collusion and nepotism will not be successful without an active role from the community. Public services are all forms of public service activities carried out by government agencies, including the central government, regional governments, State-Owned Enterprises (BUMN), and Regional-Owned Enterprises (BUMD) in the form of goods and services. [1] In Indonesia there are several strategic public services such as clean water and electricity, telephone, oil and gas, as well as several transportation services such as city buses, air ships and so on. In addition, public services are carried out in various fields through government administration or commonly known as public administration. This service is carried out both in an effort to meet community needs and as an implementation of statutory provisions. The implementation of public services is part of state administration which is the responsibility of the Government (executive) Article 4 of the 1945 Constitution. [2] 
The government is tasked with providing infrastructure, such as roads and other facilities, health facilities, adequate education and is able to prepare the next generation to live successfully in the face of global competition. In addition, the government is also tasked with producing and implementing policies for the realization of a just, prosperous, prosperous, safe and peaceful community life. It takes serious effort, courage, assertiveness, and commitment and consistency to live up to these expectations. For this reason, individual officials and civil servants must be properly prepared so that there is no misuse or abuse of office for personal or certain group interests that result in losses for public interests. The general benefit is the main task of the government. When infrastructure is properly available, the private sector also has a big role to play in partnership with the government to achieve good governance. This is where the role of the community in paying attention to governance so that it continues to run according to the existing track. [3] He further stated that there are structural barriers to genuine and substantive community participation as one of the objectives of decentralization with its implementation. Participation that has been developed has only been limited to symbolic participation (degree of tokenism), in fact it is still found that participation is manipulative so it is not worthy of being called participation. [4] This is because many local governments still view the public as not an important element in the policy-making, planning and budgeting process because they are already represented in the DPRD. This claim results in no obligation and a strong desire (especially at the institutional and operational level) to involve the community and pay serious attention to the wishes and expectations of the people in the governance processes. On the basis of these findings, there is a great need for a policy instrument that gives local governments an obligation to ensure community involvement in the process of policy making, planning, budgeting, regional asset management and public services by taking seriously the needs, aspirations and expectations of the community [5].

In accordance with the principle of openness in a democratic country, which requires State Administrators to be open to the rights of the public to obtain true, honest, and nondiscriminatory information regarding State Administration, the government has issued PP No. 68 of 1999 concerning Procedures for Implementing Community Participation in Regional Administration and Presidential Decree No. 74 of 2001 concerning Procedures for Supervision of Regional Government Administration. This Government Regulation regulates the rights and responsibilities as well as the obligations of the community and Regional Administrators in a balanced manner. This is intended so that the public can obtain legal protection in exercising their rights to obtain and convey information about Regional Administrators. The freedom to exercise this right must be accompanied by the responsibility to present actual facts and events by obeying and respecting generally recognized moral rules and applicable laws and regulations [6] [7].

\section{Urgency of Supervision}

In a simple sense, supervision means the process of measuring performance and taking action to ensure that the results (outputs and outcomes) are as desired as well as ensuring that everything runs properly according to established standards (on the right track). In the Academic Paper of the Draft Law on Public Services compiled by MP3 (People Care for Public Services), there are at least three important things for each service sector which shows that fair and quality public services must be achieved, namely:

1) Service recipient (Customer) 
A fair and quality public service is certainly the desire of the community, because apart from having to meet the minimum standards as formulated by the organizer, it is also not against the service contract which is the law for service providers and recipients. In addition, public services must also be fair in the sense of public services so that they do not only serve people who are "able to pay", but also serve people who are "unable to pay" and are less fortunate (in this case categorized in a special group). This is because, in principle, public services, especially those related to basic rights, are public rights on the one hand and state obligations on the other.

2) Service providers (Providers)

Public services that are provided fairly and with quality should be the main focus of service providers. This excellent service will certainly raise the image and it is important in evaluating the performance of each service unit, namely the satisfaction of customers or service recipients. Satisfaction is a manifestation of the success of service providers.

3) Citizen (General)

The principle of service for the basic rights of society is an obligation for the state, so everyone, without exception, is entitled to these services. This, of course, will reduce social inequality and will improve people's lives. Fair service, giving every person or citizen the opportunity to enjoy the best type of service for the improvement of their life. So, if the community has been able to get what they need, it will indirectly provide opportunities to improve their standard of living in the future. [8]

Supervision of public services is important to ensure that public services run by the state, including the private sector, are of sufficient quality according to established service standards. Supervision of public services has a very strategic role, namely:

a) Ensuring that everything runs in accordance with the mandate, vision, mission, objectives and targets of the institution / agency.

b) Knowing the level of performance accountability of each agency which can be used as a parameter to assess the success and failure of implementing the organization's mission in achieving the goals and objectives set out in the organization's strategic plan and providing a good service impact to the public.

c) Ensure that the system of use of development funds is in accordance with ethics and legal regulations that fulfill a sense of public justice, so that the principle of accountability is fulfilled.

d) Provide information about the impact of the program or intervention that needs to be carried out so that decision makers can learn about how to create an effective public service program so that it is more satisfying for the community.

The implementation of supervision can be divided into 4 types:

1) Feed forward monitoring (monitoring feed in front). This supervision is carried out before activities are started which aims to ensure clarity of targets; availability of adequate direction; availability of the required resources. And focus on quality resources.

2) Concurrent supervision (concurrent supervision). This supervision focuses on what happens during the process, which aims to monitor ongoing activities to ensure that everything is according to plan and also to reduce unwanted results.

3) Monitoring feedback (monitoring feedback). This supervision is carried out after the activity has been completed. With the aim to provide useful information to improve future performance and focus on quality results.

4) Internal-external supervision. Internal supervision provides an opportunity for selfimprovement whereas external supervision through supervision and use of formal administration. 
The supervision stage can be carried out according to the needs and objectives, namely:

a. Preliminary Control, is a preliminary supervision, one of the roles of supervision is to examine every budget proposal, especially from public service providers, both in terms of service prices, outputs and outcomes of each type of service. It is hoped that supervision will be carried out since the planning stage. Because what the government will do, the public service technical service unit can be seen from the plans made by the executive. And from the budget allocation for public services it can also be seen whether the local government will provide adequate public services to the community or not. For example, if there is not enough funding allocation for Puskesmas to provide medical services for the community, it can be ensured that the local government will not provide excellent health services to the community, especially the poor.

b. Interim Control, is intended to ensure public services run according to established standards and meet community expectations as long as services are carried out within a certain period of time. Oversight can also be directed towards the execution of the budget for public services or the duration of a regulation.

c. Post Control, apart from ensuring that public services run as expected, it is also intended for evaluation of planned targets. Supervision is expected to produce recommendations to maintain, improve or improve service quality. [9]

Thus the scope of supervision of public services consists of preventive supervision and repressive supervision.

1) Preventive Supervision, namely supervision carried out at the preparation and planning stage of an activity against a public service institution. This supervision aims at the aspects of prevention and improvement, including proposals for improvements or the formation of new regulations to improve quality standards for public services.

2) Repressive Oversight, namely supervision of the activities of a public service institution. Supervision aims to stop violations and return to its original state, either accompanied or without sanctions.

From the subject point of view, supervision is divided into Functional Supervision, Legislative Oversight, and Community supervision:

1) Functional Supervision, namely supervision carried out functionally by the government functional supervisory apparatus, such as the State Audit Board (BPK), Inspector General of State Departments / Institutions, Regional Supervisory Agency (Bawasda) of provincial, district / city government and Internal Supervisory Unit (SPI) ) BUMN / BUMD.

2) Legislative Oversight is supervision carried out by the legislative institutions (DPR, DPRD). This is explicitly stated in Law Number 22 of 2003 concerning the Composition and Position of the People's Consultative Assembly (MPR), the People's Representative Council (DPR RI), the Regional Representative Council (DPD) and the Regional People's Representative Council (DPRD) as well as in the Law Law Number 32 of 2004 concerning Regional Government. Legislative oversight is carried out through hearings, work visits, and the formation of a special committee (Pansus) or work committee (Panja). And it is not impossible, if it is considered important, the DPRD in carrying out supervision can take political action in the form of summons to the Regional Head, Interpretation Rights and Questionnaire Rights. Thus, DPRD in carrying out its function can position itself as a public service watch. In the provision of free education, for example, the DPRD must supervise the local government or SKPD make rules that prohibit schools from collecting but not allocating sufficient budget for education in the APBD. 
3) Community Oversight is supervision carried out by the community as a direct party in enjoying public services. This form of community supervision can be carried out by means of reporting and complaint mechanisms by the community against related parties. [10].

\section{$3 \quad$ Result and Discussion}

Several important notes also illustrate that public service organizations generally have a lean structure with low quality human resources. The day-to-day management that is carried out in an unprofessional manner is not visible in the complaints of the public about their poor service, as seen in cases that are no longer public secrets such as bribes (facilitation payments), bribes and corruption. Meanwhile, a survey conducted by the Sulawesi Legislative Monitoring Committee (KOPEL) in 2007 in collaboration with MP3 (People Care for Public Services) found problems including:

a) The lack of complaint mechanisms and dispute resolution related to public dissatisfaction with the delivery and quality of service products. The community is not positioned as a subject in the delivery of public services so that public complaints are often not considered important. Public complaints or complaints submitted through various media are only accommodated and there is no clarity regarding responses, follow-ups, let alone resolutions. Some SKPDs are trying to open up space for the public to submit complaints, such as through short messages (SMS), toll free calls, or making suggestion boxes. However, not all complaints have been resolved quickly and precisely. In addition, the community has not been able to monitor the process of handling complaints submitted.

b) Lack of space for public participation in service delivery. The reinstatement of the community as subjects in public services needs to be carried out as a revision process towards public service delivery. So far, what has happened is unilateral treatment by the government without involving the community in every process. The space for community involvement in the planning, implementation, and monitoring of public services is not yet open enough, and there have been no active efforts to build citizen involvement.

c) Weak evaluation of the performance of public service providers. Although since 2000 the government has made a commitment to formulating and implementing performance-based budgets, in practice this policy has never been implemented. Neither the Regional Head nor DPRD members have any evaluation tools or tools to adequately assess the performance of public service providers. Several accountability instruments made unilaterally, such as the Government Agency Performance Report (LAKIP), tend to appear to be just a formality and are not reliable enough to assess the performance of public services [11]

Community Supervision of Service Performance

As previously explained, the community has a direct impact on services because those who will enjoy services according to regulations have their right to assess services regulated by the existence of a reporting and complaint mechanism. So far, the institution that has played a role in receiving and distributing and following up on community complaints regarding service performance is the ombudsman institution which, although it is still doubted by the public, is its effectiveness. However, at least this institution has done work and carried out an inventory of public complaints reports about the performance of public services. The following is an overview of the public service performance reports reported by the ombudsman institution. [10]

As the report was received by the Ombudsman of the Republic of Indonesia, statistically the report was 339 (three hundred and thirty nine) Individual / Direct Victims reporters or $61.30 \%$. Meanwhile, there were 54 (fifty four) reports or $9.76 \%$ of Reporters who submitted 
their complaints through their Legal Counsel. Community Groups and Families of Victims each submitted reports totaling 47 (forty seven) or $8.50 \%$. Meanwhile, 34 (thirty four) reports or $6.15 \%$ of reports submitted through Non-Governmental Organizations

Based on the method of submitting complaints, the public who submitted their reports through letters were 257 (two hundred and fifty seven) reports or 46.47\%. Meanwhile, there were 244 (two hundred and forty four) reports of people who came directly or $44.12 \%$. Most of the reporters came from Central Java Province with 115 (one hundred and fifteen) reports or $20.80 \%$. Followed by DKI Jakarta with 70 (seventy) reports or $12.66 \%$, Yogyakarta Special Region with 68 (sixty eight) reports or $12.30 \%$, East Java Province with 66 (sixty six) reports or $11.93 \%$, East Nusa Tenggara Province with 65 (sixty five) reports or $11.75 \%$, and North Sumatra Province with 56 (fifty six) reports or $10.13 \%$. Meanwhile, statistically, the agencies that were reported by the public up to the third quarter of 2008 were the Police, namely 160 (one hundred and sixty) report or $28.93 \%$. Followed by Regional Government agencies with 138 (one hundred and thirty eight) reports or $24.95 \%$, Judicial Institutions with 72 (seventy two) reports or $13.02 \%$, Prosecutors with 40 (forty) reports or $7.23 \%$, Government Agencies (Ministries \& Departments) as many as 33 (thirty three) reports or 5.97\%, the National Land Agency as many as 32 (thirty two) reports or $5.79 \%$, BUMN / BUMD as many as 28 (twenty eight) reports or $5.06 \%$, and TNI as much as 14 (fourteen) reports or $2.53 \%$. Central Java Province is the province with the highest number of agencies reported by the public, namely 115 (one hundred and fifteen) reports or $20.80 \%$. Followed by DKI Jakarta with 70 (seventy) reports or $12.66 \%$, Yogyakarta Special Region with 68 (sixty eight) reports or $12.30 \%$, East Java Province with 66 (sixty six) reports or $11.93 \%$, East Nusa Tenggara Province with 65 (sixty five) reports or $11.75 \%$, and North Sumatra Province with 56 (fifty six) reports or $10.13 \%$. Of the various reports, the most maladministration substance reported was Undue Delay, which was 164 (one hundred and sixty four) reports or $33.20 \%$. This number is significantly different from the second largest substance reported by the public, namely 68 (sixty eight) reports of Arbitrary Actions or $13.77 \%$. Followed by the substance of Not Handling as many as 54 (fifty four) reports or 10.93\%, Violation of Procedure 43 (forty three) reports or $8.70 \%$, Acting Unfairly 38 (thirty eight) reports or $7.69 \%$, Request for Compensation for Money / Corruption 33 (thirty three) reports or 6.68\%, and Incompetent 30 (thirty) reports or $6.07 \%$. The substance did not handle only 36 reports last year, while this year it increased to 48 reports. The substance of requests for compensation for money / corruption in the last year amounted to 25 reports, this year it increased to 33 reports. This phenomenon shows the worsening quality of the provision of public services by government agencies, which has resulted in extreme actions, namely asking for money in return and even not providing services to the community. If this is the case, the government needs to take firm action so that public service providers can improve the quality of services to the public, one of which is to accelerate the implementation of the Public Service Law. [12]

Follow-up Community Monitoring

The ombudsman institution that has a role in receiving public reports and complaints until the end of September 2008 has followed up $93.67 \%$ of all public reports and initiative investigations, the remaining $6.33 \%$ is still in process. The Ombudsman has issued a letter to the Reported Party in the context of requesting clarification as many as 170 (one hundred and seventy) letters or $30.74 \%$, Recommendations as much as 59 (fifty nine) letters or $10.67 \%$, Follow-up on requests for clarification of 10 (ten) letters or $1.81 \%$. Meanwhile, 76 (seventy six) reports or $13.74 \%$ could not be followed up because the substance of the problem being complained was not the authority of the Ombudsman of the Republic of Indonesia. Meanwhile, 100 (one hundred) reports or $18.08 \%$ are still waiting for additional data from 
Reporters in the context of Completing the Data. Meanwhile, the Reported Party's response in the third Quarter of 2008 decreased compared to the same period last year. If last year in the same period there were 110 (one hundred and ten) response letters from 637 (six hundred and thirty seven) public reports, in this period there were 81 (eighty one) response letters from 553 (five hundred and thirty three) reports, or decreased by about $26.36 \%$. This can be due to the fact that there are still many agencies that do not understand the role and function of the Ombudsman in overseeing the provision of public services. However, it could also be because the agency has taken steps to resolve it without informing the Ombudsman. For example, until this period the Ombudsman has received information from the Reporting Party verbally that their complaint has been resolved by the agency concerned in 2 (two) reports. Not to mention counting Reporters whose problems had been resolved but did not inform the Ombudsman of their progress. The Reported Party's response to the follow-up of the Ombudsman of the Republic of Indonesia who answered to Conduct Research as much as 3 (three) letters or $3.85 \%$, Follow up reports on 8 (eight) letters or $10.26 \%$, Explanation 67 (sixty seven) or $82.72 \%$. In addition, the Ombudsman also receives responses from related agencies which usually receive a copy of the Ombudsman's follow-up, namely 1 (one) letter or $1.28 \%$. With the passing of the Law on the Ombudsman of the Republic of Indonesia, the issue of submitting information to the Ombudsman regarding the follow-up of the Ombudsman's clarification or recommendation must be the concern of every public agency. The Law on the Ombudsman of the Republic of Indonesia in Article 33 states that if the Reported Party does not provide an answer for $2 \times 14$ days, then the Reported Party is deemed not to use the right to answer, and then the Ombudsman can issue Recommendations which must be implemented by the Reported Party.

Review of Law No. 25 of 2009 on Public Services

As explained earlier, public services as part of the efforts to achieve good governance can be seen through 3 strategic steps. First, the interaction between the State (represented by the government) and its citizens, including various groups or institutions outside the government inside public service. Ideally, this interaction forces the government as a service provider to provide the best service for its citizens. Second, public service is an area in which the principles of good governance can be better articulated. Good governance values such as effectiveness, efficiency, non-discrimination, justice, high responsiveness and high accountability can be realized in the delivery of public services. These values are easily visible and applied in public services within the framework of good governance. Third, public services involve all interests within the state. Government, society, and market mechanisms have an interest in better public services. The fate of a government, both at the central and regional levels, depends on the built public services. The trust and legitimacy of their power comes from users of public services, namely the community. The current legitimacy of power is determined by the government's siding with its people directly. Bad forms of service lead to public distrust of a government regime. Based on this assumption, one of the efforts made to improve the quality of public services is by issuing Law No. 25 of 2009 on public services. The following are some of the provisions, especially with regard to supervision in implementation. [5]

1) Subject of Supervision

According to the law, supervision of the implementation of public services is carried out by internal supervisors and external supervisors. Internal supervision of the implementation of public services is carried out through supervision by a direct superior in accordance with statutory regulations; and supervision by functional supervisors in accordance with statutory 
regulations. Meanwhile, external supervision of the implementation of public services is carried out through:

a) Supervision by the public in the form of reports or complaints from the public in the provision of public services;

b) Supervision by an ombudsman in accordance with statutory regulations; and

c) Supervision by the People's Representative Council, Provincial Regional Representative Council, Regency / City Regional Representative Council. (Article 35 of Law No. 25 of 2009)

2) Form of Operator Response to supervision

One form of supervision, especially supervision from the community, is complaints. As a response in following up on complaints, the Administrator is obliged to provide a means of complaints and assign an executor who is competent in managing complaints and is obliged to announce the name and address of the person in charge of managing the complaint and the means of complaint provided. The organizer is obliged to manage complaints originating from service recipients, recommendations from the ombudsman, the People's Representative Council, the Provincial Regional People's Representative Council, and the Regency / City Regional People's Representative Council within a certain time limit. The organizer is obliged to follow up on the results of the complaint management. (Article 36 of Law No. 25 of 2009).

3) Monitoring / complaint mechanism

The mechanism of supervision of the community as regulated above is through complaints. Complaints are made by the public if the implementation of public services:

a) The organizer that does not fulfill the obligation and / or violates the prohibition; and

b) Executors who provide services that are not in accordance with service standards.

The complaint is addressed to the organizer, ombudsman, and / or the People's Representative Council, the Provincial Regional People's Representative Council, the Regency / City Regional People's Representative Council. (Article 40 of Law No. 25 of 2009). Complaints as referred to above are filed by every person who is injured or by other parties who receive the power to represent him. The complaint is made no later than 30 (thirty) days after the complainant receives service. In their complaint, the complainant can submit a claim for compensation. In certain circumstances, the name and identity of the complainant may be withheld. While the Complaints mechanism submitted in writing must contain:

a) Full name and address;

b) A Description of the service that is not in accordance with service standards and a description of the material or immaterial losses suffered;

c) Proposed settlement requests; and

d) Place, time of submission, and signature. (Article 42 of Law No. 25 of 2009)

The written complaint can be accompanied by evidence to support the complaint. In the event that the complainant needs documents related to his complaint from the organizer and / or executor to support his proof, the organizer and / or executor is obliged to provide it. (Article 43 of Law No. 25 of 2009).

4) Acceptance of Complaints

The organizer and / or ombudsman is obliged to respond to a written complaint by the public no later than 14 (fourteen) days after the complaint is received, which at least contains complete or incomplete information on the written complaint material. In case the complaint material is incomplete, the complainant complements the material of the complaint is no later than 30 (thirty) days after receiving the response from the organizer or ombudsman as informed by the organizer and / or the ombudsman. In the event that the complaint file is not completed within that time, the complainant is deemed to have withdrawn the complaint. 
(Article 44 of Law No. 25 of 2009). In the event the organizer commits an act against the law in the provision of public services as regulated in the public service law, the public can file a lawsuit against the organizer to the court. Filing a lawsuit against the organizer, does not eliminate the obligation of the organizer to implement the ombudsman and / or organizer's decision. The filing of a lawsuit against the law is carried out in accordance with statutory regulations. (Article 52 of Law No. 25 of 2009). In the event the organizer is suspected of committing a criminal act in the provision of public services as regulated in this law, the public can report the organizer to the authorities. (Article 53 of Law No. 25 of 2009).

Government Regulation Substance Recommendations Concerning Supervision of Public Service Delivery

1) Public Supervisory Institutions and their supervisory positions, according to the law, supervision of the administration of public services is carried out by internal supervisors and external supervisors. Meanwhile, the community can carry out external supervision of the implementation of public services (article 35). On the other hand, Article 39 explains that one of the roles of the community is to form a supervisory institution. As well as Article 39 also stipulates that community involvement in public services starts from the preparation of service standards to evaluation and awarding. The question that then needs to be explained in the regulation is what is the mechanism for establishing the Community Monitoring Institution? What is the supervisory position? When referring to the supervision as Schermerhorn (2001), what is: Feed forward monitoring (monitoring the bait in front). Concurrent supervision (concurrent supervision). Monitoring feedback (monitoring feedback). Of course, this must be considered as the overlap with the authority of existing institutions such as the Ombudsman and the DPR.

2) Supervision by DPR / DPRD, in this regulation the supervision of the implementation of public services by DPR / DPR only stipulates that the DPR / DPRD accepts complaints from the public (article 40). This means that the supervision of DPR / DPRD is only limited when there are complaints from the public? This is what then still needs to be explained further. So far, oversight by the DPR / DPRD has invited many debates including internal ones. There are those who argue that the authority of DPR / DPRD in supervision is limited to policies and is macro-strategic as stipulated in PP 79 of 2005 concerning Guidelines for the Supervision of Regional Government Administration. On the other hand, many practitioners are of the view that the DPR / DPRD members need to carry out more detailed supervision, including in the context of management.

If you follow the description above, the role of DPR / DPRD is actually strategic if it follows three stages in the public service process, and this is done according to the needs and objectives, namely:

a. Preliminary Control, is the supervision of DPR / DPRD members during budget discussions. In this preliminary supervision, DPR / DPRD members are expected to play a role in examining every budget proposal, especially from public service providers, both in terms of service prices, outputs and outcomes of each type of service. It is hoped that DPRD members will carry out supervision since the planning stage. This is because what the government, as well as the public service technical service units will do, can be seen from the plans made by the executive. And from the budget allocation for public services it can also be seen whether the local government will provide adequate public services to the community or not. For example, if there is not enough funding allocation for Puskesmas to provide medical services for the community, it can be ensured that the local government will not provide excellent health services to the community, especially the poor. 
b. Interim Control, is intended to ensure public services run according to established standards and meet community expectations as long as services are carried out within a certain period of time. Oversight can also be directed towards the execution of the budget for public services or the duration of a regulation.

c. Post Control, apart from ensuring that public services run as expected, is also intended for evaluation of planned targets. The supervision is expected to produce recommendations to maintain, improve or improve service quality.

In this regulation, of course, it is also relevant to explain in detail the form of supervision of DPR / DPR not only limited to receiving complaints as explained in Article 40 or sufficient, it is only explained in the internal regulation regarding the supervision function of DPR / DPRD.

a. The provisions regarding complaint managers in service providers, Article 36 states that public service providers are obliged to provide a means of complaints and assign executors who are competent in managing complaints. There are two things to underline for further explained in the regulations, namely. First, the existence of a means of complaints is important because in practice the submission of public complaints is carried out through various media formally through official letters, verbally meeting directly, via SMS, making statements in the mass media, through demonstrations, and so on. Of course, it needs to be considered important in the regulations to determine the standard for complaints and the standard of means provided in responding to complaints. Second, a competent implementer, of course, the implementer in this case is possible from the internal service provider. For this reason, the competent standard here must be explained with the qualifications of the implementer. Especially here are objective and independent qualifications that need attention

b. Complaint Resolution Mechanisms by DPR / DPRD, the mechanism for resolving complaints against public servants in the law that is regulated is the resolution of complaints by ombudsman (article 46) and by public service providers (article47). Meanwhile, if it is based on article 40 it explains that public complaints can be submitted to other than the two institutions, namely to the DPR / DPRD. The question is how the settlement of complaints by the DPR / DPRD itself is, is it relevant to be discussed in this regulation or is it sufficient to regulate the oversight mechanism by the DPR / DPRD. However, it must be noted that the experience shows that complaints to the DPR / DPRD tend not to be followed up on the grounds that they do not understand the mechanism or that understanding has become the responsibility of other institutions. The remaining matters relating to the supervision of the implementation of public services that are not yet clearly regulated in Law No. 25 of 2009 can use a reference to the implementing regulations of the Ombudsman this needs to be done so that there is no overlap in the application of the rules. [13]

\section{Conclusions}

Indonesia is a democratic country so that the highest sovereignty rests in the hands of the people, the people also play a central role in carrying out the supervisory function of the implementation of regional government by the regional head. Community supervision is needed in realizing public participation in order to create effective, efficient, clean and free governance from corruption, collusion and nepotism. Public participation in overseeing the running of government has been regulated and guaranteed by the Prevailing Laws so that in practice it must be encouraged again where the community is required to be more active and critical in observing any policies or regulations that have been set or that will be stipulated by the regional government in order to maintain governance. The regions remain in accordance 
with the plans and the prevailing laws and regulations, so that governance is carried out according to the will of the community.

\section{References}

[1] C. A., "Sistem pengawasan terhadap penyelenggaraan pemerintah daerah kabupaten: pembahasan peraturan perundangan di bidang pengawasan," Sist. Pengawas. terhadap penyelenggaraan pemerintah Drh. kabupaten pembahasan Peratur. perundangan di Bid. Pengawas., 2004.

[2] E. S. Holle, "Pelayanan Publik Melalui Electronic Government: Upaya Meminimalisir Praktek Maladministrasi Dalam Meningkatan Public Service," Sasi, vol. 17, no. 3, p. 21, 2011.

[3] M. S. DRS. RUSDAN, "Mewujudkan Birokrasi Pemerintah Terhubungkan Sebagai Pelayan Publik."

[4] S. Lukow, "Eksistensi Good Governance Dalam Sistem Pemerintahan Daerah di Kota Manado,” J. Huk. Univ. Sam Ratulangi, vol. 1, no. 5, pp. 130-142, 2013.

[5] J. Naranjo, "Implementasi Pengawasan Melekat dan Fungsional Terhadap Penyelenggaraan Pemerintahan Daerah (Implementation of Internal and Functional Controlling on Implementation of Local Government)," Appl. Microbiol. Biotechnol., vol. 85 , no. 1, pp. 2071-2079, 2014.

[6] Timothy Tennent, "PP No 68 1999," J. Chem. Inf. Model., vol. 53, no. 9, pp. 16891699, 2013.

[7] R. Indonesia, "Keputusan presiden republik Indonesia nomor 74 tahun 2001 tentang tata cara pengawasan penyelenggaraan pemerintahan daerah," pp. 1-12, 2001.

[8] C. Wibowo and H. Harefa, "Urgensi Pengawasan Organisasi Kemasyarakatan oleh Pemerintah,” J. Bina Praja, vol. 07, no. 01, pp. 01-19, 2015.

[9] A. Matondang, "Pembinaan Aparatur Pemerintahan dalam Pelaksanaan Tugas di Bagian Umum Sekretariat Kantor Bupati," JPPUMA J. Ilmu Pemerintah. dan Sos. Polit. UMA (Journal Gov. Polit. Soc. UMA), vol. 3, no. 2, pp. 160-174, 2015.

[10] H. Wibawa, "Pengawasan Ombudsman Terhadap Penyelenggara Negara Dan Pemerintahan (Studi Perbandingan Dengan Pengawasan PERATUN)," 2010.

[11] S. Tahir, "JURNAL SOSIAL DAN POLITIK ISSN 2301-6876 KINERJA KOMITE PEMANTAU LEGISLATIF ( KOPEL ) DALAM MELAKUKAN PENGAWASAN TERHADAP PELAKSANAAN Supratman Tahir JURNAL SOSIAL DAN POLITIK," vol. 9, pp. 115-123, 2019.

[12] S. S. Dawes and M. A. Gharawi, "Transnational public sector knowledge networks: A comparative study of contextual distances," Gov. Inf. Q., vol. 35, no. 2, pp. 184-194, 2018.

[13] D. Stisip and M. Sinjai, "MODEL PENGAWASAN DPRD TERHADAP PEMERINTAH DAERAH DI KABUPATEN SINJAI Juharni Dosen Fisipol Universitas Bosowa Makassar Umar." 